agriTECH, 41 (3) 2021, 231-237

\title{
Antioxidant Activity and Consumer Preference of Brown Algae Sargassum hystrix Juice as a Functional Drink
}

\author{
Punky Kusuma Damayanti, Siti Ari Budhiyanti, Amir Husni* \\ Department of Fisheries, Faculty of Agriculture, Universitas Gadjah Mada, \\ Jalan Flora, Gedung A4, Bulaksumur, Yogyakarta 55281, Indonesia \\ *Corresponding author: Amir Husni, Email: a-husni@ugm.ac.id
}

Submitted: Juli 20, 2017; Revised: February 12, 2018; April 27, 2020; Acceptance: July 6, 2020

\begin{abstract}
Sargassum hystrix juice is a functional beverage made from S. hystrix through the immersion process, crushing, filtering, and pasteurization. Therefore, this study aims to determine the effect of $S$. hystrix concentration on antioxidant activity, level of consumer acceptance, and chemical composition of the juice. The fresh $S$. hystrix used were washed, immersed for three days, and blended at a concentration of 10, 20,30, 40, and 50\%, respectively. Meanwhile, the qualities of juice that were observed include yield, antioxidant activity, total phenol, water, ash, protein, and fiber content, formol number, total sugar, total plate count, and sensory analysis. The results showed that the $S$. hystrix juice had a value of yield $43.00-85.67 \%, \mathrm{pH} 7.5$, antioxidant activity 20.50 $44.57 \%$, total phenolic $32.78-293.11 \mathrm{mg} \mathrm{GAE} / \mathrm{g}$, water $93.03-95.39 \%$, ash $0.36-6.34 \%$, protein $0.88-4.96 \%$, crude fiber $0.41-5.04 \%$, formol number $15-21.67 \mathrm{~mL} \mathrm{~N} \mathrm{NaOH} / 100 \mathrm{~mL}$, total sugar $3.10-4.61 \%$, total plate count

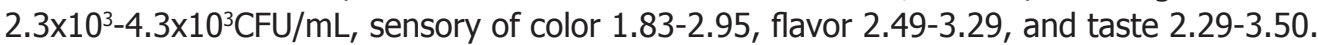

Keywords: Antioxidant; functional drink; juice; Sargassum hystrix

\section{INTRODUCTION}

The consumption patterns of Indonesians, especially in urban communities, have a change of eating habits from natural into fast foods that are rich in fat and free radicals (Fagbemi et al., 2013). This condition was one of the factors that caused an increase in the prevalence of degenerative diseases such as coronary heart disease, diabetes mellitus, hypertension, heart disease, stroke, and some types of cancer (Barhe and Tchouya, 2016). Meanwhile, the presence of free radicals in the body leads to degenerative diseases such as diabetes mellitus, narrowing of blood vessels, coronary heart disease, stroke, and cancer (Kang et al., 2010).

Disease prevention is carried out by setting nutrient consumption such as natural antioxidant that is capable to fight degenerative diseases. These antioxidants delay or prevent the occurrence of free radical autooxidation reactions (Farag et al., 2003). Currently, the antioxidant activity of various food is one of the most widely studied topics due to its implications on health, especially the potential as a functional ingredient (Balboa et al., 2013). Therefore, the attention on the use of natural antioxidants is increasing and one source of these is algae. Budhiyanti et al. (2011) have studied 
the antioxidant activity of the cytoplasm and membrane fractions of Sargassum hystrix. However, the utilization of antioxidant compounds from brown algae S. hystrix in food is limited, therefore, more studies are required on its application in food.

Functional beverages contain ingredients that improve health status or prevent certain diseases (Tangkeallo and Widyaningsih, 2014). Juice is a beverage derived from fruit or vegetables and smoothies (Caswell, 2009), the ones from algae are very rare. Furthermore, Juice is usually served cold, hence, it is easy to maintain and minimize the damage of the antioxidant compounds contained in S. hystrix. Therefore, this study was conducted to produce functional drinks such as $S$. hystrix juice that contains natural antioxidants.

\section{MATERIALS AND METHODS}

\section{Materials}

The primary equipment used for Sargassum hystrix juice processing includes homogenizer (Philips, Tokyo, Japan), analytical balance (Denver Instrument Company AA-200, New York, USA), Kjeldahl flask, electric stove (Maspion, Indonesia), Spectrophotometer Microlab 300 (Elitech Group, France), ELISA reader (Microplate Reader, Japan), and incubator (Isuzu Incubator, Japan). The main materials used for the processing include $S$. hystrix sample from Sepanjang Beach, Gunung Kidul, Folin-Ciocalteu, and DPPH from Sigma-Aldrich (St Louis, $\mathrm{MO}, \mathrm{USA}), \mathrm{Na}_{2} \mathrm{CO}_{3}$ and $\mathrm{HNO}_{3}$ from DifcoFisher Scientific (Ottawa, ON, Canada).

\section{Sargassum hystrix Preparation and Immersion}

The samples of brown algae S. hystrix were collected at Pantai Sepanjang, Gunung Kidul, from January to June 2016 and washed using clean water to remove impurities and residual seawater. Meanwhile, the immersion method based on Supirman et al., (2013) with modification was conducted by soaking $250 \mathrm{~g}$ of $S$. hystrix into $750 \mathrm{~mL}$ of water and adding lemon juice until a pH value of 3 is reached. Furthermore, $100 \mathrm{~g}$ of fresh pandan leaves were for three days to eliminate the fishy smell and every 12 hours, water used was changed to avoid saturation of dirt and salt. In addition, the fresh and soaked samples were tested for antioxidant activity, total phenol content, and proximate analysis.

\section{Sargassum hystrix Juice Processing}

The materials required needed to make the juice were brown alga S. hystrix, sugar, and water. After immersion, the sample was blended with water and
Tabel 1. Formulation ratio of materials for making Sargassum hystrix juice.

\begin{tabular}{lccccc}
\hline \multirow{2}{*}{ Materials } & \multicolumn{5}{c}{ Concentration of S. hystrix (\%) } \\
\cline { 2 - 6 } & 10 & 20 & 30 & 40 & 50 \\
\hline S. hystrix $(\%, \mathrm{w} / \mathrm{v})$ & 20 & 40 & 60 & 80 & 100 \\
Water $(\mathrm{mL})$ & 170 & 150 & 130 & 110 & 90 \\
Sugar $(\%, \mathrm{w} / \mathrm{v})$ & 10 & 10 & 10 & 10 & 10 \\
Total volume $(\mathrm{mL})$ & 200 & 200 & 200 & 200 & 200 \\
\hline
\end{tabular}

sugar by the concentration based on threshold test and S. hystrix juice was stored in a freezer $\left(-18^{\circ} \mathrm{C}\right)$ before further analysis. Meanwhile, the juice was processed based on Iriani et al. (2005) with modifications. The formula of $S$. hystrix juice is shown in Table 1.

\section{Sample Analysis}

The sample was analyzed to obtain the value of yield (Magro et al., 2015), pH (Zainoldin, 2009), antioxidant activity (Zubia et al., 2009), total phenol (Kang et al., 2010), the content of water, ash, protein, crude fiber, total sugar, formol number, total plate count (AOAC, 2019), and the level of consumer acceptance (Setyaningsih et al., 2010). Meanwhile, a consumer acceptance analysis was conducted by 80 untrained panelists to assess the parameter of color, flavor, and taste of each juice treatment. This assessment was conducted by giving a score from 1 to 5 ( $1=$ strongly dislike, $2=$ dislike, $3=$ neutral, $4=$ like, and $5=$ strongly like).

\section{Statistical Analysis}

Chemical analysis data were analyzed using ANOVA with a $95 \%$ confidence level and the results showed a significant difference which was followed by the TukeyHSD test. Meanwhile, consumer acceptance data were analyzed using Kruskal-Wallis and when there was a significant difference, it was followed by Mann-Whitney test. This data analysis was carried out with SPSS 20.0.

\section{RESULTS AND DISCUSSION}

\section{Yield}

The yield of $S$. hystrix juice is shown in Table 2 and the result showed that its higher concentration had a lower value of the yield. Meanwhile, Magro et al. (2016) stated that the grape juice with and without the addition of enzyme pectinase produced 69.85 and $75.83 \%$ of yield, respectively. Iriani et al. (2005) also stated that the yield of kuini mango juice with the addition of 
pectinase enzymes had a value of 78.10 to $84.92 \%$. Therefore, the high-water content in the processing of the juice made $S$. hystrix more soluble in water which led to higher yield, while more solvent produced a higher volume of extract (Kamaluddin et al., 2014).

\section{pH}

The $\mathrm{pH}$ of each $S$. hystrix concentration had the same value which was 7.5 (Table 2). This showed that the concentration of $S$. hystrix in the juice did not affect the $\mathrm{pH}$ which tends to be neutral. In this study, the destruction process and pasteurization time, as well as the amount of sugar used in each treatment were the same, therefore, there was no real effect on the juice produced. Moreover, Harjantini and Rustanti (2015) stated that the functional beverage of srikaya yogurt jelly with the addition of carrageenan has a $\mathrm{pH}$ of 4.33 to 5.74. Furthermore, Pamungkas et al. (2014) stated that jelly drinks of hantap leaf extract have a $\mathrm{pH}$ value of 7.87 .

\section{Antioxidant Activity}

The antioxidant activity of this juice depends on the concentration of $S$. hystrix as shown in Table 2, where the highest activity was $43.91 \%$ for $40 \%$ concentration. Moreover, Husni et al. (2015b) stated that fast drinks with the addition of $S$. polycystum ethanolic extract have an antioxidant activity of 25.7 to $65.41 \%$ while yogurt has $72.34 \pm 0.01 \%$ at a concentration of $6000 \mathrm{ppm}$
(Husni et al., 2015a). Similarly, Pamungkas et al. (2014) stated that jelly drinks of hantap leaf extract have an antioxidant activity of $20.93 \%$. Furthermore, the heat process applied to the food processing and $\mathrm{pH}$ value of food also influenced the stability of the product's antioxidant activity (Tensiska et al., 2003).

\section{Total Phenol Content}

Total phenol content as shown in Table 2 indicated that $S$. hystrix concentrations influenced its content in the juice. Meanwhile, the concentration of $50 \%$ had the highest value of total phenol content, while the lowest was at 10 and $20 \%$ concentrations. The correlation analysis showed that there was a strong and positive correlation between total antioxidant activity and total phenol content. Moreover, Husni et al. (2015b) stated that the greater the addition of $S$. polycystum extract in fast drinks, the more the antioxidant activity and positively correlated with total phenol. The relationships between total phenol and antioxidant activity of $S$. hystrix juice are shown in Figure 1.

Brown macroalgae compounds have potential as antioxidants, namely, polysaccharides, phenolic compounds, lipids, pigments, vitamins, terpenoids, and sterols (Balboa et al., 2013). Meanwhile, fast drinks with the addition of $S$. polycystum ethanolic extract had a total phenol content from 27.74 to $100.36 \mathrm{mg} \mathrm{GAE} / \mathrm{g}$ (Husni et al., 2015b). Similarly, Pamungkas et al. (2014) stated that jelly drinks of hantap leaf extract had a total phenol content of $10.6 \mathrm{GAE} / 100 \mathrm{~g}$. When compared to

Tabel 2. Parameter values of $S$. hystrix juice

\begin{tabular}{lccccc}
\hline \multirow{2}{*}{ Parameters } & \multicolumn{5}{c}{ The concentration of Sargassum hystrix } \\
\cline { 2 - 6 } & $10 \%$ & $20 \%$ & $30 \%$ & $40 \%$ & $50^{\circ}$ \\
\hline Yield & $85.67^{\mathrm{d}}$ & $72.33^{\mathrm{c}}$ & $64.33^{\mathrm{b}}$ & $57.67^{\mathrm{b}}$ & $43.00^{\mathrm{a}}$ \\
$\mathrm{pH}$ & 7.50 & 7.50 & 7.50 & 7.50 & 7.50 \\
Antioxidant Activity & $20.50^{\mathrm{a}}$ & $27.29^{\mathrm{b}}$ & $37.09^{\mathrm{c}}$ & $43.91^{\mathrm{d}}$ & $44.57^{\mathrm{d}}$ \\
Total Phenol Content & $32.78^{\mathrm{a}}$ & $39.78^{\mathrm{a}}$ & $131.51^{\mathrm{b}}$ & $179.05^{\mathrm{b}}$ & $293.11^{\mathrm{c}}$ \\
Water Content & $93.03^{\mathrm{a}}$ & $95.39^{\mathrm{b}}$ & $95.05^{\mathrm{b}}$ & $95.12^{\mathrm{b}}$ & $94.77^{\mathrm{b}}$ \\
Ash Content & $0.79^{\mathrm{ab}}$ & $0.36^{\mathrm{a}}$ & $5.58^{\mathrm{ab}}$ & $5.68^{\mathrm{ab}}$ & $6.34^{\mathrm{b}}$ \\
Protein Content & $0.88^{\mathrm{a}}$ & $2.33^{\mathrm{ab}}$ & $2.63^{\mathrm{b}}$ & $3.79^{\mathrm{ab}}$ & $4.96^{\mathrm{b}}$ \\
Crude Fiber Content & $0.41^{\mathrm{a}}$ & $0.79^{\mathrm{a}}$ & $2.85^{\mathrm{b}}$ & $5.04^{\mathrm{c}}$ & $4.97^{\mathrm{c}}$ \\
Total Sugar Content & $4.61^{\mathrm{b}}$ & $4.13^{\mathrm{b}}$ & $4.11^{\mathrm{b}}$ & $3.18^{\mathrm{a}}$ & $3.10^{\mathrm{a}}$ \\
Total Plate Count & $2.3 \times 10^{3}$ & $3.0 \times 10^{3}$ & $2.8 \times 10^{3}$ & $4.3 \times 10^{3}$ & $3.1 \times 10^{3}$ \\
Formol Number & $15.00^{\mathrm{a}}$ & $15.67^{\mathrm{ab}}$ & $18.00^{\mathrm{ab}}$ & $21.33^{\mathrm{b}}$ & $21.67^{\mathrm{b}}$ \\
Color Preference & $2.95^{\mathrm{b}}$ & $2.95^{\mathrm{b}}$ & $2.79^{\mathrm{b}}$ & $2.95^{\mathrm{b}}$ & $1.83^{\mathrm{a}}$ \\
Flavour Preference & $2.83^{\mathrm{ab}}$ & $3.29^{\mathrm{c}}$ & $3.01^{\mathrm{c}}$ & $2.89^{\mathrm{b}}$ & $2.49^{\mathrm{a}}$ \\
Taste Preference & $3.50^{\mathrm{c}}$ & $3.09^{\mathrm{b}}$ & $3.34^{\mathrm{b}}$ & $3.15^{\mathrm{bc}}$ & $2.29^{\mathrm{a}}$ \\
\hline
\end{tabular}

Values in the same line with different letters are significantly different at $p<0.05$ 


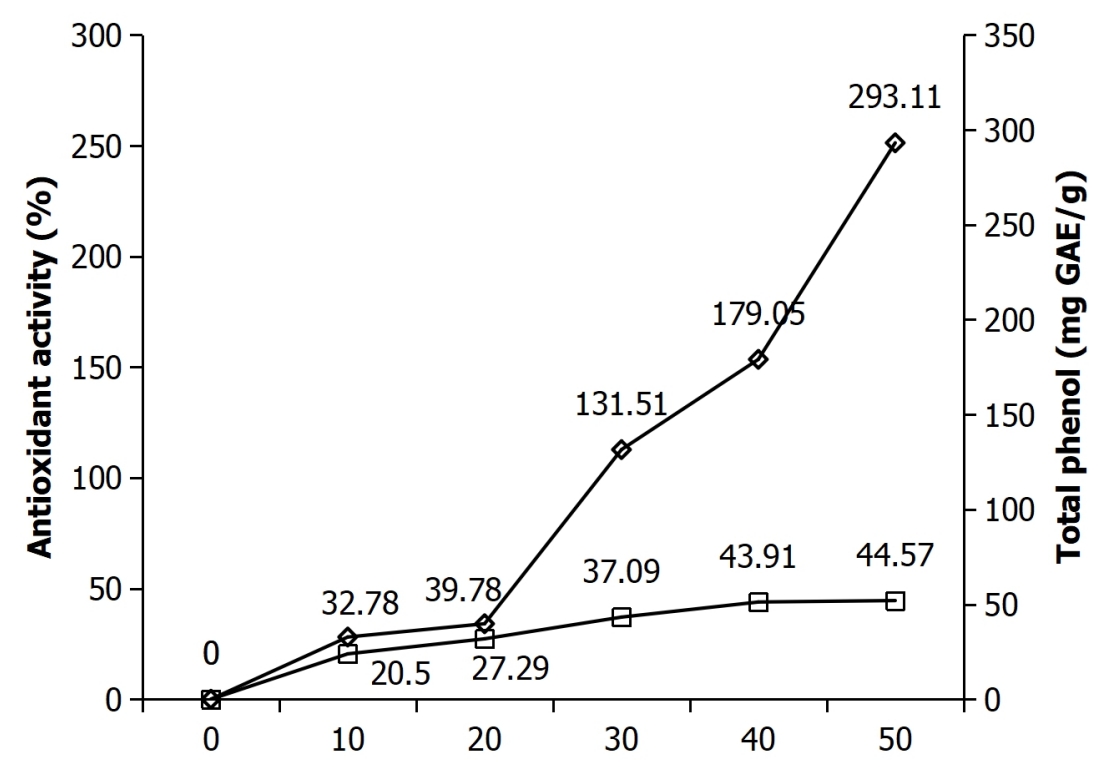

Concentration of Sargassum hystrix (\%)

$\square$ Antioxidant activity $\leadsto$ Total phenol

Figure 1. Relationships between total phenol and antioxidant activity of Sargassum hystrix juice

some of these studies, the total phenolic content of the S. hystrix juice was significantly high.

\section{Proximate Analysis}

The water content of $S$. hystrix juice varied from 93.03 to $95.39 \%$ as shown in Table 2. Meanwhile, Pamungkas et al. (2014) stated that the water content of jelly drinks from hantap leaf extract was $87.37 \%$ and yogurt with the addition of $S$. polycystum ethanolic extract varied from 77.69 to $85.76 \%$ (Husni et al., 2015a). Therefore, S. hystrix juice had a higher water content because it was liquid.

Table 2 showed that the concentration of $S$. hystrix juice affected ash content, therefore, a greater concentration of $S$. hystrix produced higher ash content. Moreover, Husni et al. (2015b) stated that fast drinks with the addition of $S$. polycystum ethanolic extract had ash content from 0.06 to $11.54 \%$. Furthermore, Wibowo and Fitriyani (2012) stated that the ash content of fast drinks Eucheuma cottonii were 18 to $25 \%$, while yogurt with the addition of $S$. polycystum ethanolic extract had an ash content of 0.84 to $1.17 \%$ (Husni et al., 2015a). When compared to previous studies, the ash content values of $S$. hystrix juice were fairly small ranging from 0.36 to $6.34 \mathrm{ppm}$.

The protein content of the juice was affected by the concentration of $S$. hystrix and the range was 0.88 to $4.96 \%$ as shown in Table 2 . A previous study by Pamungkas et al. (2014) stated that jelly drinks of hantap leaf extract had a protein content of $0.10 \%$, while yogurt with the addition of S. polycystum ethanolic extract had 3.22 to $6.53 \%$ (Husni et al., 2015a). Therefore, the protein content of $S$. hystrix juice was not significantly different from a previous study which stated that a higher concentration of $S$. hystrix in the juice leads to more protein content.

\section{Crude Fiber Content}

The crude fiber content of $S$. hystrix juice was 0.41 to $4.97 \%$ as shown in Table 2 . and is not significantly different from Wibowo and Fitriyani (2012) which stated that the Eucheuma cottonii fast drinks had a fiber content of 5.25 to $11.83 \%$. Similarly, Harjantini and Rustanti (2015) stated that the functional beverage srikaya yogurt jelly with the addition of carrageenan had a fiber content of 2.14 to $3.40 \%$.

\section{Total Sugar Content}

The effect of $S$. hystrix concentration on the total sugar content of juice is shown in Table 2 . Meanwhile, the amount of sugar used in juicing was $10 \%$, however, not all was soluble, some were filtered or lost during the process. There was an insignificant difference between the total sugar content of $S$. hystrix juice of $10 \%, 20 \%$, and $30 \%$, and also between $40 \%$ 
and $50 \%$ concentrations. The total sugar content was affected by the amount of sugar in the product. Furthermore, the total sugar content of $S$. hystrix juice ( 3.10 to $4.61 \%$ ) was very small compared to the fast drinks with the addition of $S$. polycystum ethanolic extract (76.13 to $87.18 \%$ ) (Husni et al., 2015b), due to the $10 \%(\mathrm{w} / \mathrm{v})$ that was used. Therefore, a higher concentration of $S$. hystrix in juice reduces the total sugar content of the juice.

\section{Total Plate Count}

Table 2 showed that there was no influence of S. hystrix concentration in the juice on the total plate count. The total plates count at 10,20,30,40, and 50\% were $2.3 \times 10^{3}, 3.0 \times 10^{3}, 2.8 \times 10^{3}, 4.3 \times 10^{3}$, and $3.1 \times 10^{3}$ $\mathrm{CFU} / \mathrm{mL}$, respectively. This value was not significantly different when compared to pineapple juice fortified by chitosan. Meanwhile, Husniati and Oktarina (2012) stated that the addition of chitosan on pineapple juice had a total plate count of $8.40 \times 10^{3}-9.19 \times 10^{3} \mathrm{CFU} / \mathrm{mL}$.

\section{Formol Number}

The influence of $S$. hystrix concentration against the formol number of juice is shown in Table 2 which indicated that its concentration affected the formol number of juice $(p<0.05)$. This showed that a higher concentration of $S$. hystrix increased the formol number of juice which ranges from 15.00 to $21.67 \mathrm{~mL} \mathrm{~N} \mathrm{NaOH} / 100 \mathrm{~mL}$. Meanwhile, increased formol numbers indicated their proteolytic activity in degrading proteins into amino acids, peptides, and ammonia. This number had fulfilled SNI 01-37191995, where the minimum requirement formol number of fruit juice was $15 \mathrm{~mL} \mathrm{~N} \mathrm{NaOH} / 100 \mathrm{~mL}$. Furthermore, Su et al. (2005) stated that the ratio of formol number to total protein contributes to the delicious flavor.

\section{Sensory Properties of S. hystrix Juice}

\section{Color}

Table 2 showed that there was an insignificant difference between the juice color and $S$. hystrix at a concentration of $10,20,30$, and $40 \%$, respectively. Meanwhile, the $S$. hystrix concentration of $50 \%$ was significantly different from other treatments, therefore, higher concentration reduced the levels of juice color that was dominated by the green and ranges from 1.83 to 2.95. Husni et al. (2015b) stated that fast drinks with the addition of $S$. polycystum ethanolic extract had color values from 2.4 to 3.2. Similarly, the color value of yogurt with the addition of $S$. polycystum ethanolic extract was 2.67 to 3.08 (Husni et al., 2015a).

\section{Flavor}

The flavor of juice was affected by $S$. hystrix concentration as shown in Table 2. Meanwhile, the flavor of $S$. hystrix juice at the concentration of 10 , $20,30,40$, and 50 were 2.83, 3.29, 3.01, 2.89, and 2.49 , respectively. This value is approximately equal to instant drink with the addition of S. polycystum ethanolic extract that had flavor values from 1.29 to 3.66 (Husni et al., 2015b), while yogurt had flavor values from 2.42 to 3.10 (Husni et al., 2015a).

\section{Taste}

The taste of the juice was affected by $S$. hystrix concentration as shown in Table 2. Meanwhile, the taste of $S$. hystrix juice for the concentration of 10,20 , 30,40 , and 50 were 3.50, 3.09, 3.34, 3.15, and 2.29, respectively. The taste of $S$. hystrix juice was higher compared to fast drinks of $S$. polycystum ethanolic extract that had a taste of 1.32 to 3.59 (Husni et al., 2015b). Similarly, yogurt with the addition of $S$. polycystum ethanolic extract had a taste of 2.15 to 2.76 (Husni et al., 2015a). Meanwhile, Supirman et al. (2013) stated that the addition of lime in $S$. filipendula drink can not eliminate the fishy smell, therefore, preference level panelists to the drink are low.

\section{CONCLUSION}

Based on the results, the selection of appropriate formulation for $S$. hystrix juice depends on treatment with a high value of the antioxidant activity, total phenol content, and high sensory hedonic value. In this study, the best formulation was the treatment of S. hystrix juice concentration by $40 \%$ that has high antioxidant activity and sensory value. Therefore, a higher concentration of $S$. hystrix in the juice leads to higher antioxidant activity and positively correlated with total phenol content.

\section{ACKNOWLEDGMENT}

This study was funded by the Directorate of Research and Service, Directorate General of Higher Education, Ministry of Education and Culture, the Republic of Indonesia through a scheme of Excellence Research Grants of Higher Education organized by the Institute of Research and Community Services Universitas Gadjah Mada 2014, Number: LPPM -UGM/430/LIT/2014, March 3, 2014. This paper is part of the first author's undergraduate Thesis. 


\section{CONFLICT OF INTEREST}

The authors declare that there is no conflict of interest.

\section{REFERENCES}

AOAC. (2019). Official Methods of Analysis of The Association of Analitycal Chemist. Washington D.C.

Bahre, T.A., \& Tchouya, G.R.F. 2016. Comparative study of the anti-oxidant activity of the total polyphenols extracted from Hibiscus Sabdariffa L., Glycine max L., Merr., yellow tea and red wine through reaction with DPPH free radicals. Arabian Journal of Chemistry 9: 1-8.

Balboa, E.M., Conde, E., Moure, A., Falque, E., \& Dominguez, H. (2013). In vitro antioxidant properties of crude extracts and compounds from brown algae. Food Chemistry 138: 1764-1785. https://doi.org/10.1016/j. foodchem.2012.11.026

Budhiyanti, S.A., Raharjo, S., Marseno, D.W., \& Lelana, I.Y.B. (2011). Free radical scavenging, metal chelating, and singlet oxygen quenching activity of fractionated brown seaweed Sargassum hystrix extract. Journal of Biological Sciences 11: 288-298. DOI: 10.3923/jbs.2011.288.298

Caswell, H. (2009). The role of fruit juice in the diet: an overview. Nutrition Bulletin 34: 273-288. DOI: 10.1111/j.1467-3010.2009.01760.x

Fagbemi, N.T., Folashade, B.A., Ifesan, B.O., \& Badejo, A. (2013). Antioxidant properties of cold and hot water extracts of cocoa, hibiscus flower extract, and ginger beverage blends. Food Research International 52: 490-495. https://doi.org/10.1016/j. foodres.2013.01.021

Farag, R.S., El-Baroty, G.S., \& Basuny, A.M. (2003). The influence of phenolic extracts obtained from the olive plant (cvs. Picual and Kronakii), on the stability of sunflower oil. International Journal of Food Science and Technology 38: 81-87. DOI: 10.1046/j.13652621.2003.00665.x

Harjantini, U., \& Rustanti, N. (2015). Total Bakteri Asam Laktat, pH, dan Kadar Serat Minuman Fungsional Jelly Yoghurt Srikaya dengan Penambahan Karagenan [Total Lactic Acid Bacteria, pH, and Fiber of Functional Jelly Yoghurt Srikaya with Carrageenan Addition]. Journal of Nutrition College 4: 514-519. https://doi.org/10.14710/ jnc.v4i4.10156

Husniati \& Oktarina, E. (2012). Pengaruh penambahan kitosan pada jus nenas terhadap shelf life [The effect of chitosan addition in pineapple juice toward shelf life]. Jurnal Hasil Penelitian Industri 25: 11-17. http:// ejournal.kemenperin.go.id/jhpi/article/view/ 2864/2139
Husni, A., Pereira, M.M., \& Ustadi (2015a). Aktivitas antioksidan dan tingkat penerimaan konsumen pada yoghurt yang diperkaya dengan ekstrak Sargassum polycistum [Antioxidant activity and consumer preference of Yoghurt enriched with Sargassum polycystum Extract]. Jurnal Pengolahan Hasil Perikanan Indonesia 18: 108118. http://dx.doi.org/10.17844/jphpi.v18i2.10606

Husni, A., Ariani., D., \& Budhiyanti, S.A. (2015b). Aktivitas antioksidan dan tingkat penerimaan konsumen pada minuman instan yang diperkaya dengan ekstrak Sargassum polycistum [Antioxidant activity and consumer preference of instant drink enriched with Sargassum polycystum extract]. Agritech 35: 368-376. https://doi.org/10.22146/agritech.9320

Iriani, E.S., Said, E.G., Suryani, A., \& Setyadjit (2005). Pengaruh konsentrasi penambahan pektinase dan kondisi inkubasi terhadaprendemen dan mutu jus mangga kuini (Mangifera odorata Griff) [Effects of pectinase concentration and incubation condition on yields and quality of kuini mango juice (Mangifera odorata Griff)]. Jurnal Pascapanen 2: 11-17.

Kamaluddin, M.H., Lutfi, M., \& Hendrawan, Y. (2014). Analisa pengaruh microwave assisted extraction (MAE) terhadap ekstraksi senyawa antioksidan Catechin pada daun teh hijau (Camellia sinensis) (kajian waktu ekstraksi dan rasio bahan pelarut) [Effect of microwave assisted extraction (MAE) on antioxidant compounds extraction of catechins in green tea leaves (Camellia Sinensis) (Extraction time and ratio raw material : solven]. Jurnal Keteknikan Pertanian Tropis dan Biosistem 2: 147-155.

Kang, C., Jin, Y.B., Lee, H., Cha, M., Shon, E., Moon, J., Park, C., Chun, S., Jung, E., Hong, J., Kim, S.B., Kim, J., \& Kim, E. (2010). Brown algae Ecklonia cava attenuates type 1 diabetes by activating AMPK and AKT signaling pathways. Food and Chemical Technology 48: 509-516. https://doi.org/10.1016/j.fct.2009.11.004

Magro, L.D., Dalagnol, L.M.G., Manfroi, V., Hertz, P.F., Klein, M.P., \& Rodrigues, R.C. (2016). Synergistic effects of pectinex ultra clear and lallzyme beta on yield and bioactive compounds extraction of Concord grape juice. Food Science and Technology 72: 157-165. https://doi. org/10.1016/j.Iwt.2016.04.046

Pamungkas, A., Sulaeman, A., \& Roosita, K. (2014). Pengembangan produk minuman jeli ekstrak daun hantap (Sterculia oblongata R. Brown) sebagai alternatif minuman fungsional [Product development of jelly drink as an alternative of functional food from hantap leaves Sterculia oblongata R.Brown extract)]. Jurnal Gizi dan Pangan 9: 195-202. http://dx.doi.org/10.25182/jgp.2014.9.3.\%25p

Setyaningsih, D., Apriyantono, A., \& Sari, M.P. (2010). Analisis Sensori untuk Industri Pangan dan Agro [Sensory Analysis for Food and Agro Industry]. IPB Press, Bogor. 
Supirman, Kartikaningsih, H., \& Zaelanie, K.(2013). Pengaruh perbedaan $\mathrm{pH}$ perendaman asam jeruk nipis (Citrus auratifolia) dengan pengeringan sinar matahari terhadap kualitas kimia teh alga coklat (Sargassum fillipendula) [Effect of difference of $\mathrm{pH}$ immersion of lemon acid (Citrus auratifolia) with sun drying to chemical quality of brown algae tea (Sargassum fillipendula)]. THPi Student Journal 1: 46-52.

Su, N.W., Wang, M.L., Kwok, K.F., \& Lee, M.H.(2005). Effects of temperature and sodium chloride concentration on the activities of proteases and amylases in soy sauce Koji. Journal Agricultural Food Chemistry 53: 15211525. DOI: $10.1021 /$ jf0486390

Tangkeallo, C., \& Widyaningsih, T. (2014). Aktivitas serbuk minuman instan berbasis miana kajian jenis bahan baku dan penambahan serbuk jahe [Antioxidant activity of miana based drink powder materials and additional ginger powder]. Jurnal Pangan dan Agroindustri 2: 278284.

Tensiska, C.H., Wijaya, N., \& Andarwulan (2003). Aktivitas antioksidan ekstrak buah andaliman (Zanthoxylum acanthopodium DC) dalam beberapa sistem pangan dan kestabilan aktivitasnya terhadap kondisi suhu dan $\mathrm{pH}$ [Antioxidative activity of Andaliman fruit extract ( $Z$. acanthopodium DC.) on several food system and its antioxidative stability on temperature and $\mathrm{pH}$ influence]. Jurnal Teknologi dan Industri Pangan 15: 29-39.

Wibowo, L., \& Fitriyani, E. (2012). Pengolahan rumput laut (Eucheuma cottoni) menjadi serbuk minuman instan. (Processing of seaweed (Eucheuma cottoni) into an instant drink). Vokasi 8: 101-109.

Zainoldin, K.H., and Baba, A.S.(2009). The effect of Hylocereus polyrhizus and Hylocereus undatus on physicochemical, proteolysis, and antioxidant activity in yogurt. World Academy of Science, Engineering and Technology 60: 361-366.

Zubia, M., Marie, S.F., Veronique, K., Klervi, L.L., Valerie, S.P., Fauchon, M., \& Eric, D. (2009). Antioxidant and antitumoural activities of some Phaeophyta from Brittany coasts. Food Chemistry 116: 693-701. https:// doi.org/10.1016/j.foodchem.2009.03.025 